\title{
Culture and Entrepreneurial Self Efficacy: Comparative Analysis at Provincial Level in Pakistan
}

\author{
Muhammad Mansoor Ali ${ }^{a}$, Hajra Ihsan ${ }^{b}$, Afia Mushtaq ${ }^{c}$ \\ a Assistant Professor, Department of Economics, NUML, Islamabad, Pakistan \\ Email:mmali@numl.edu.pk \\ ${ }^{\mathrm{b}}$ Assistant Professor, Department of Economics, IIUI, Islamabad, Pakistan \\ Email: Hajra.ihsan@iiu.edu.pk \\ ${ }^{c}$ Assistant Professor, University of Management and Technology, Lahore, Pakistan \\ Email: Mushtaque.afia64@gmail.com
}

\begin{tabular}{|c|c|}
\hline ARTICLE DETAILS & ABSTRACT \\
\hline & \multirow{12}{*}{$\begin{array}{l}\text { The debate about embeddedness of entrepreneurship in cultural } \\
\text { dimensions has not found any conclusive theory but still there is ample } \\
\text { evidence that culture has impact on intention of entrepreneurial activity. } \\
\text { The culturally legitimate vocational choices affect the efficacy to make an } \\
\text { entrepreneurial startup. This is directly linked with not only the } \\
\text { economic activity but also for creating businesses with the available } \\
\text { local resources. Entrepreneurial self-efficacy reflects the personal beliefs } \\
\text { of individuals in their own abilities and regarding opportunity } \\
\text { recognition and risk propensity. The study conducted the analysis by } \\
\text { comparing entrepreneurs in four provinces of Pakistan (Punjab, Khyber } \\
\text { Pakhtunkhwa, Sindh and Balochistan) and found significant differences } \\
\text { in factors describing self-efficacy. MGCFA revealed the stability of the } \\
\text { research instrument across the provinces thus factor loadings for } \\
\text { different provinces can be compared. Entrepreneurs in Punjab have } \\
\text { relatively stronger entrepreneurial self-efficacy in contrast with other } \\
\text { provinces. The policy intervention should be reflective of the situation of } \\
\text { each province, and public policy related to business environment should } \\
\text { be more liberal while in other provinces supportive of entrepreneurs } \\
\text { through institutional support to new business developers. }\end{array}$} \\
\hline Acc & \\
\hline Avai & \\
\hline Кеуи & \\
\hline oneurshin $k$ & \\
\hline Effects of Psychological, & \\
\hline Emotional, Social and Co & \\
\hline Factors on Decision Making, & \\
\hline Public Policy & \\
\hline & \\
\hline & \\
\hline DOI: $10.47067 /$ reads.v7i2.356 & \\
\hline
\end{tabular}

(C) 2021 The authors. Published by SPCRD Global Publishing. This is an open access article under the Creative Commons Attribution-

NonCommercial 4.0

Corresponding author’s email address: mmali@numl.edu.pk

\section{Introduction}

The experience of the nations during the recessions has revealed that small businesses with their innovations in products and services emerging with newer strategies to survive and thrive always lead the way to economic recovery. It is ability of any society to create enabling circumstances for entrepreneurial actions as effectuation of entrepreneurial expertise is to logically think for new business startup with ability to survive and thrive in an unpredictable future. In the recent past most 


\section{Review of Economics and Development Studies, Vol. 7 (2) 2021, 257-266}

remarkable business ventures have emerged for those innovative businesses that were built in an unknown and unknowable future market situation (Fritsch \& Wyrwich, 2018). It is entrepreneurial efficacy that enables entrepreneurs to shape this unpredictable future and create organizations that delve upon ways to continuously embrace newness and creativity. When stock market is down and generating signals of stress in the economy, entrepreneurial startups endeavors do not add to it instead become a source of generating new jobs. Hayes and Malone (2009) acknowledged this fact and indicated that only entrepreneurs rather any governmental action could lead the US out of financial crisis. Therefore, the entrepreneurial activity has become a source of sustainable growth for any economy not only for efficient use of available scarce resources but also for social harmony and prosperity. The natural, agricultural and human resources are at the disposal of entrepreneur to create value for creating new enterprises. Thus, the entrepreneurial literature comprehends the individual attributes of an entrepreneur, the organizational setting it creates for success, and the macroeconomics environment (industry, legal, national and global) (Farah \& Ali, 2018).

Among factor driven economies Pakistan not only has lowest number of established firms and economic policy makers continue to ignore and neglect the role of entrepreneurship (GEM Pakistan Report, 2011). Chemin (2008) cited that annual new firms entry rate in Pakistan was $7 \%$ as compared to $10.2 \%$ in industrialized countries found in entrepreneurship survey of 84 developing and industrial countries for the period 2003-2005 by The World Bank Group. But when it comes to size of the firms, business landscape in Pakistan is dominated by relatively smaller firms. Small and Medium Enterprise Development Authority (SMEDA) reported that in 2015 there were about 3.5 million private firms (registered and non-registered) employing $80 \%$ of the non-agricultural labor force but $90 \%$ of these firms have less than 100 employees. The share of small and medium sized firms in exports is $25 \%$ with 40\% contribution in GDP (Economic Census of Pakistan, 2016).

The study is generally concerned with assessing the potential of individuals to try to attempt establishing an entrepreneurial business. It requires understanding of personal internal strengths, efficient financial and market management, and awareness of ecological factor. All these factors determine the rate of success of these attempts in agriculture and non-agriculture based businesses. But study will be confined to entrepreneurial startups that are based on agriculture factor inputs due to the fact that still around $70 \%$ of population of Pakistan is directly or indirectly employed in agriculture sector. Furthermore, the data collection will not only be restricted to few of the important cities, but also within those cities in which entrepreneurs will be available. The instruments of the study will be refined on the basis of preliminary data collected from entrepreneurial startups located in Rawalpindi and Hattar. The quality of data will depend largely on the time preferences of the respondents. As the study is to determine the efficacy of the individuals, therefore, the conclusions drawn will be limited to individuals and not the corporate entities as a whole.

\section{Literature Review}

Aggregate entrepreneurial behavior is strongly rational deliberately indulged to create a synergy for systematic transformation of existing ways to produce goods and services with the use of knowledge, technology and capital. The 'Four Key Factors' constituting entrepreneurial process are: talent, technology, know-how, and capital (Gibson, 1991). Each factor represents a separate entity but is interdependent and together creates synergy for creating a new organization. Effectuation enables a person to use these factors effectively to create entrepreneurial intentions and new uses of available resources in the face of uncertain and unpredictable future.

'Excellence in asking more of yourself than what others do' describes the concept of self-efficacy. 


\section{Review of Economics and Development Studies, Vol. 7 (2) 2021, 257-266}

Self-efficacy measures a person's competence within a specific framework, focusing on the selfassessment of abilities to perform specific tasks aligned with goals and standard rather than in comparison with capabilities of others (Fritsch \& Wyrwich, 2018). Self-efficacy is closely linked to important entrepreneurial outcomes like start-up intentions (Kruger et.al. 2000), new venture growth and personal success of entrepreneur (Markman et.al. 2002). Therefore, the entrepreneurial selfefficacy is central to long-run growth of any economy. The entrepreneurial self-efficacy is reflected in the creation of new organizations like corporations, social services delivery, and innovative initiatives (Fuller et al., 2018).

They understand the importance of enacting systems for business management i.e. financial management, planning cash flows, marketing, human resources development, and strategic planning, etc. (Chen, Greene \& Crick, 1998). These varying insights into the entrepreneurial behavior can lead us to conclusion that an entrepreneur has a distinctive persona, approach towards life, enthusiasm, vision and commitment to transform plans into reality through a well thought out business plan and to cease every opportunity of innovation (Linan \& Chen, 2009). Therefore, entrepreneur needs to have very strong personality traits that are shaped by the personal background, experience, education, training, and environment. Such personality traits make many scholars to say that entrepreneurs are born rather made (Flora, 2006).

Entrepreneurs are differentiated from non-entrepreneurs generally on the basis of individual level factors (Shane, 2003). At this level, certain attributes differentiate individuals on the basis of the way they discover, evaluate, and take advantage of entrepreneurial opportunities. Entrepreneurs are more achievement-orientated than their peers (Collins, Hannon \& Smith 2004). The motive of selfrealization and independence drives an entrepreneur to think out of the ordinary and come up with ideas that can be translated into new goods and services (Carter et al. 2003; Douglas and Shepherd 2002). Self-efficacy and having belief in one's competence to pursue a new venture is important for every entrepreneur (Chen, Greene \& Crick, 1998; McGee et al., 2009; Townsend, Busenitz \& Arthurs, 2010).

This self-belief makes them to stand for relatively more risk, therefore, manifesting higher risk propensity for their projects. Entrepreneurs also face risk of carrying the 'stigma' in case of failure of their project (Stewart \& Roth, 2004). Schumpeter (1934) went on to say that entrepreneur is the person who breaks the existing economic order down to create new products and services, create new opportunities and create new firms. Therefore, an entrepreneur is more creative than nonentrepreneurs (Lee \& Wong, 2004). If the project thrives, entrepreneur fulfills the dream of financial success but more than this, the contended feeling of success as a social norm enables him to earn and create the social network that is enabling for entrepreneurial culture (Elster, 1989; Turker \& Selcuk, 2009).

\section{Data \& Methodology}

The research in theory of entrepreneurial self-efficacy has not yet developed one-factor construct that can describe the entrepreneurial competence. In a similar effort Sarasvathy (2001) described four principles of effectuation enabling a person to take up risk prone business decision in an unknowable future: bird in hand; affordable loss; pre-commitments, and flexibility. On the contrary, causation is measured with single construct especially by Chandler et al. (2011) to explain the entrepreneurial actions. Another strand of thinking in this perspective is entrepreneurial bricolage that describes the behavior of entrepreneur in terms of making the best use of available resources and creating value for the business by innovation facing a resources constraint (Baker \& Nelson, 2005). 


\section{Review of Economics and Development Studies, Vol. 7 (2) 2021, 257-266}

Researchers like McGee et.al. (2009) used the principles of self-efficacy to develop scales for entrepreneurial startups. They adjusted the principles of self-efficacy for entrepreneurial startups by creating these dimensions: searching (3 items); planning (4 items); marshalling (3 items); implementing-people (6 items); implementing-financial (3 items), and; attitude towards venturing (3 items). The study used these measures of effectuation to generate data of entrepreneurial startups from agricultural sector of Pakistan.

Table 1: Measurement Scales of Entrepreneurial Efficacy

\begin{tabular}{|l|l|c|c|}
\hline \multicolumn{1}{|c|}{ Scale } & \multicolumn{1}{|c|}{ Number of Factors } & $\begin{array}{c}\text { Number of } \\
\text { Items }\end{array}$ & Reference \\
\hline DeNoble-scale & $\begin{array}{l}\text { Developing new product or market opportunities; } \\
\text { building an innovative environment; initiating } \\
\text { investor relationships; defining core purpose; } \\
\text { coping with unexpected challenges, and; } \\
\text { developing critical human resources }\end{array}$ & 25 & $\begin{array}{l}\text { De Noble, Jung, } \\
\text { \& Ehrlich, 1999 }\end{array}$ \\
\hline Chen-scale & $\begin{array}{l}\text { Marketing; innovation; management; risk-taking, } \\
\text { and; financial control. }\end{array}$ & 20 & $\begin{array}{c}\text { Chen, Greene, \& } \\
\text { Crick, 1998 }\end{array}$ \\
\hline McGee-scale & $\begin{array}{l}\text { Searching; planning; marshalling; implementing } \\
\text { people; implementing financial, and; attitude } \\
\text { towards venturing. }\end{array}$ & 22 & $\begin{array}{c}\text { McGee, } \\
\text { Peterson, } \\
\text { Mueller, \& }\end{array}$ \\
\hline
\end{tabular}

The McGee-scale used the factors identified by other researchers (e.g. Cox et al., 2002; Mueller \& Goic, 2003) to develop their linear phase-based measure: searching, planning, marshalling, and implementing. The McGee-scale of Entrepreneurial Efficacy has-items measure consisting of six distinct factors specifically related to: searching, planning, marshalling, implementing people, implementing financial, and attitude towards venturing (McGee, Peterson, Mueller, \& Sequeira, 2009): searching - (3 items), planning - (4 items), marshalling - (3 items), implementing People - (6 items), implementing Financial - (3 items), and attitude towards Venturing - (3 items). Therefore, study used McGee-scale for assessing entrepreneurial efficacy.

The analysis of pilot study revealed some of the items did not comply with the minimum statistical requirements to be considered consistent with construct of effectuation. As the study in using standardized scales of measurement, therefore, study did not modify the instruments instead tried to identify the respondents on the basis of general self-efficacy (GSE). The study identified the responses that were showing homogeneous or non-responses and those were either discarded or re-interviewed. The study then had to select those respondents that gave reliable responses for empirical analysis and scored high on the scale of GSE. 
Table 2: Detail of Sample and Sub-Sample

\begin{tabular}{|l|c|c|c|c|c|}
\hline & $\begin{array}{c}\text { Sample Size in } \\
\text { Pilot Study }\end{array}$ & $\begin{array}{c}\text { Proportion in } \\
\text { Pilot Study }\end{array}$ & $\begin{array}{c}\text { Sample } \\
\text { Size }\end{array}$ & $\begin{array}{c}\text { Missing } \\
\text { Values }\end{array}$ & $\begin{array}{c}\text { Admissible for } \\
\text { Analysis }\end{array}$ \\
\hline Punjab & 97 & $37 \%$ & 296 & 63 & 233 \\
\hline KPK & 68 & $29 \%$ & 232 & 25 & 207 \\
\hline Sindh & 21 & $16 \%$ & 128 & 29 & 99 \\
\hline Balochistan & 26 & $18 \%$ & 144 & 23 & 121 \\
\hline Total & 212 & $100 \%$ & 800 & 140 & 660 \\
\hline
\end{tabular}

The data was collected from all four provinces of the country and the instruments used were validated through EFA. The study also conducted the multi grout confirmatory factor analysis to ascertain the stability of the research instrument.

As empirical analysis is based on structural equation modeling, the study conducted confirmatory factor analysis (CFA) for assessing validity and reliability of instruments to reach pertinent decisions and analysis about entrepreneurs in agricultural sector of Pakistan. CFA retains those factors that have standard factor weights from 0.5 to 0.7 for all items provided high degree of reliability (Cronbach's Alpha > 0.7), average variance extracted (AVE > 0.5) and construct reliability (CR > 0.7) for all constructs (Hair, Jr., Hult, Ringle, \& Sarstedt, 2017). As the comparison of different categories is done in the study, the study used information of CFA instead of Chi-Square test for assessing the significance of results. Chi-Square test works well for categories of same size, but is affected largely because of difference in degrees of freedom. The study produced different sized categories for comparison and CFA is used to make comparison as it is based mostly on average measures (Fornell \& Larcker, 1981).

\section{Results and Discussion}

Societies with high supply of entrepreneurs have a favorable culture and personality orientation that crates an entrepreneurial mindset (Minniti \& Bygrave, 2003). Entrepreneurship is promoted in a society that has a dynamic orientation exhibiting such cognition that encourages an overall adjustment to change and support it within legal and economic framework (Foxcroft et al., 2002). 
Review of Economics and Development Studies, Vol. 7 (2) 2021, 257-266

Table 3: Invariance of Entrepreneurial Efficacy

\begin{tabular}{|l|c|c|c|c|c|c|c|}
\hline \multicolumn{1}{|c|}{ Model } & $\chi^{2}$ & $\Delta \chi^{2}$ & Df & $\Delta$ df & CFI & $\Delta$ CFI & RMSEA \\
\hline Model 1: Configural invariance & 89.23 & - & 147 & - & 0.911 & - & 0.03 \\
\hline $\begin{array}{l}\text { Model 2: Metric Invariance: first- } \\
\text { order factor loadings invariant }\end{array}$ & 112.33 & 23.1 & 161 & 14 & 0.901 & 0.01 & 0.039 \\
\hline $\begin{array}{l}\text { Model 3: Metric Invariance: first- } \\
\text { and second-order factor loadings } \\
\text { invariant }\end{array}$ & 132.47 & 20.14 & 168 & 4 & 0.899 & 0.002 & 0.048 \\
\hline $\begin{array}{l}\text { Model 4: Scalar Invariance: first- } \\
\text { and second-order factor loadings } \\
\text { and intercepts of first order }\end{array}$ & 167.98 & 35.51 & 182 & 14 & 0.881 & 0.018 & 0.06 \\
\hline $\begin{array}{l}\text { Model 5: Scalar Invariance: first- } \\
\text { and second-order factor loadings, } \\
\text { and intercepts of measured } \\
\text { variables and first-order factors } \\
\text { invariant }\end{array}$ & 202.67 & 34.69 & 186 & 4 & 0.801 & 0.08 & 0.11 \\
\hline
\end{tabular}

Individual and collective development of entrepreneurial culture is a reinforcing process that transcends not just at the cultural level but also at sub cultural level. Therefore, ethnicity and race are also differentiating factors that influence tendency of individuals and groups to indulge in creative and innovation based business activity.

The results of invariance indicate that the second order scalar invariance could not be established but still the first order metric and scalar invariance along with second order scalar invariance is enough to establish that the research component is stable across the sub-sectors of agricultural sector of Pakistan. As the instrument is stable across all the four categories, therefore, the factor loadings of different items can be compared.

Table 9 Province wise Constructs and Comparison of Item Means for Entrepreneurial Effectuation

\begin{tabular}{|c|c|c|c|c|c|c|c|c|}
\hline & \multicolumn{4}{|c|}{$\begin{array}{c}\text { Cronbach's } \alpha \\
\text { AVE } \\
\text { CR }\end{array}$} & \multicolumn{4}{|c|}{$\begin{array}{l}\text { Factor } \\
\text { Loading }\end{array}$} \\
\hline & Punjab & KPK & Sindh & Balochistan & Punjab & KPK & Sindh & Balochistan \\
\hline Searching - & 0.88 & 0.71 & 0.70 & 0.64 & & & & \\
\hline Brainstorm to & 0.57 & 0.40 & 0.40 & 0.38 & .77 & .62 & .52 & .65 \\
\hline generate a new idea & 0.80 & 0.44 & 0.45 & 0.42 & .76 & .57 & .67 & .55 \\
\hline Need for a new & & & & & .78 & .71 & .71 & .66 \\
\hline product or service & 0.82 & 0.68 & 0.62 & 0.67 & & & & \\
\hline Designing a & 0.79 & 0.79 & 0.79 & 0.79 & .87 & .67 & .57 & .51 \\
\hline product or service & 0.83 & 0.54 & 0.52 & 0.51 & .84 & .66 & .64 & .56 \\
\hline $\begin{array}{l}\text { Planning - } \\
\quad \text { Estimate customer }\end{array}$ & & & & & .82 & .62 & .72 & .72 \\
\hline demand & & & & & .71 & .63 & .61 & .71 \\
\hline Determine a & 0.86 & 0.78 & 0.66 & 0.88 & & & & \\
\hline competitive price & 0.62 & 0.64 & 0.32 & 0.74 & .81 & .77 & .48 & .77 \\
\hline
\end{tabular}


Review of Economics and Development Studies, Vol. 7 (2) 2021, 257-266

\begin{tabular}{|c|c|c|c|c|c|c|c|c|}
\hline 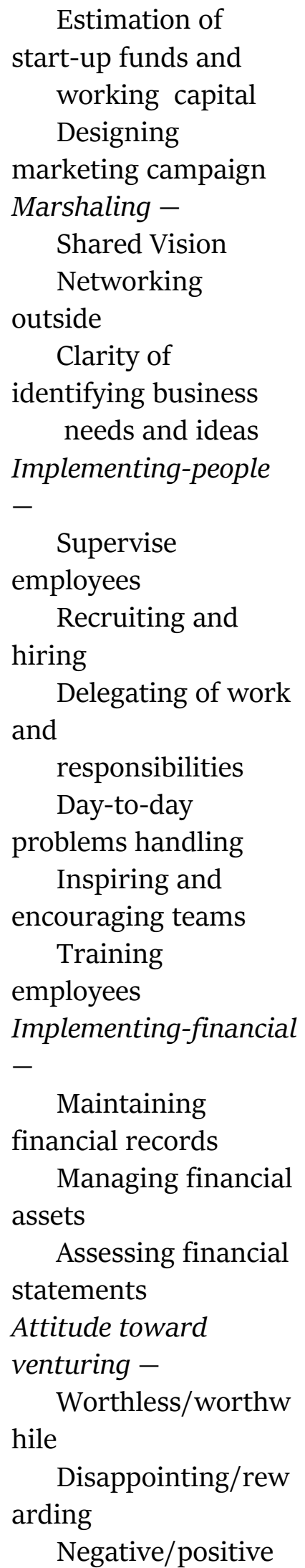 & $\begin{array}{l}0.84 \\
0.72 \\
0.93 \\
0.82 \\
0.72 \\
0.93\end{array}$ & $\begin{array}{l}0.88 \\
0.71 \\
0.95 \\
0.84 \\
0.72 \\
0.92\end{array}$ & $\begin{array}{l}0.74 \\
0.75 \\
0.85 \\
0.77 \\
0.74 \\
0.87\end{array}$ & $\begin{array}{l}0.69 \\
0.77 \\
0.79 \\
0.71 \\
0.75 \\
0.83\end{array}$ & $\begin{array}{l} \\
.78 \\
.77 \\
.80 \\
\\
.84 \\
.81 \\
.74 \\
.88 \\
.86 \\
.81 \\
.91 \\
.71 \\
.91\end{array}$ & $\begin{array}{l}.71 \\
.72 \\
.70 \\
.72 \\
.73 \\
.64\end{array}$ & $\begin{array}{l}.78 \\
.77 \\
.80 \\
.77 \\
.71 \\
.74 \\
.68 \\
.78 \\
.71 \\
.88 \\
.71 \\
.68\end{array}$ & $\begin{array}{l}.71 \\
.72 \\
.70 \\
.72 \\
.63 \\
.61 \\
.72 \\
.67 \\
.58 \\
.71 \\
.61 \\
.78\end{array}$ \\
\hline $\begin{array}{l}\text { Punjab: } \chi^{2}=143 \cdot 34, p \\
<. \mathrm{oo} ; \mathrm{GFI}=.94 ; \mathrm{CFI}= \\
.88 ; \mathrm{RMSEA}=.05\end{array}$ & \multicolumn{2}{|c|}{$\begin{array}{l}\text { KPK: } \chi^{2}= \\
116.18, p< \\
.00 ; \mathrm{GFI}=.90 ; \\
\mathrm{NFI}=.90 ; \\
\text { RMSEA }=.06\end{array}$} & \multicolumn{3}{|c|}{$\begin{array}{l}\text { Sindh: } \chi^{2}=64.11, p<.00 ; \mathrm{GFI} \\
=.91 ; \mathrm{CFI}=.91 ; \mathrm{RMSEA}=.05\end{array}$} & \multicolumn{3}{|c|}{$\begin{array}{l}\text { Balochistan: } \chi^{2}=94.68, p \\
<.00 ; \text { GFI }=.92 ; \text { CFI }= \\
.90 ; \text { RMSEA }=.04\end{array}$} \\
\hline
\end{tabular}




\section{Review of Economics and Development Studies, Vol. 7 (2) 2021, 257-266}

There are few studies that have studied the impact of family and national culture on self-efficacy of individual that intend to be entrepreneurs (Bandura, 2012). But Bandura (2012) asserts that people do not spend life neither independent of the society not entirely accordingly to the wishes and inspirations of others.

The interplay and interdependencies of individuals create reactive and harmonizing behaviors shaping cooperation and conflict situation that have varying degree of manifestation depending upon the social structure to diffuse or enforce them. Therefore, self-efficacy also has to develop within individual self and the societal setting individual interacts with. Entrepreneurial self-efficacy is thus related with likelihood of an individual to follow an entrepreneurial life style which is different from successfully crating an entrepreneurial business startup (Farah \& Ali, 2018). The respondents of the study are form different regions of Pakistan, therefore, the study compared differences in entrepreneurial self-efficacy due to belonging to different regions. This analysis does not address the issue of difference in self-efficacy of entrepreneurs from different ethnic backgrounds working in a common geographical region.

The results reveal that the entrepreneurs belonging to Punjab have highest level of entrepreneurial self-efficacy while it is lowest in Balochistan. Entrepreneurs from Khyber Pakhtunkhwa and Sindh seem to be having almost similar entrepreneurial self-efficacy. The differentiating factor in Punjab is the high degree of need to search for entrepreneurial opportunities as compared to other provinces. Once the entrepreneurial opportunity is identified, then the entrepreneurs in Punjab put a lot of effort to plan and make the startup a reality. The information about social and professional networks is also easily available to them and there is relatively more developed markets that can help in making better decisions about pricing and positioning. The factor markets are also more developed as compared to other provinces and help the entrepreneur to decide upon the quality and level of production at the inception of the firm. The relative size of cities is also larger in Punjab and it has more agglomeration impact than rest of the country except Karachi. The organizational founding is also subject to entrepreneurial potential of the region in particular and economy in general. Therefore, large cities and information networks provide a conducive environment for new entrepreneurial activity. Individual entrepreneurs generally in organized markets and highly agglomerated regions tend to start modest which help them to attract investments for growth of their firms. Therefore, there is a reinforcing impact of ecology and culture on entrepreneurial activity which is also seen in populous regions of Pakistan. Possible reasons for relatively low level of entrepreneurial efficacy in Balochistan may be due to less population density but in Khyber Pakhtunkhwa is due to turbulent circumstances for more than three decades. A large portion of Pashto speaking population is doing business in other provinces outside Khyber Pakhtunkhwa. The interviews with entrepreneurs revealed that instead of expanding the business and launching big they prefer to expand the product lines. This fact can also be verified by looking at the results of the analysis.

\section{Conclusion and Recommendations}

There exists a difference in entrepreneurial self-efficacy among the people belonging to different provinces in Pakistan. Entrepreneurs in Pakistan are not in general well versed with letting the others to share their vision due to paying less attention to marketing and image building of their business. It can be inferred from the analysis that the effectual enterprise development in Pakistan has a limited growth potential due to paying less attention to marketing and financial management. This may have implications for entrepreneurs to have export outlook of their businesses especially when due to CPEC and other international commitments economy of Pakistan is open to foreign competition. The policy intervention should be reflective of the situation of each province, and public policy related to business 


\section{Review of Economics and Development Studies, Vol. 7 (2) 2021, 257-266}

environment should be more liberal while in other provinces supportive of entrepreneurs through institutional support to new business developers.

\section{References}

Bandura, A. (2012). On the functional properties of perceived self-efficacy revisited. Journal of Management, 38(1), 9-44.

Carter, N. M., Gartner, W. B., Shaver, K. G., \& Gatewood, E. J. (2003). The career reasons of nascent entrepreneurs. Journal of Business Venturing, 18(1), 13-39.

Chemin, M. (2008). Entrepreneurship in Pakistan: Government policy on SMEs. Environment for entrepreneurship, Internationalisation of Entrepreneurs and SMEs. 18(1): 13-39.

Chen, C. C., P. G. Greene and A. Crick. (1998). Does entrepreneurial self-efficacy distinguish entrepreneurs from managers? Journal of Business Venturing, 97(2): 295-316.

Collins, L., Hannon, P. D., \& Smith, A. (2004). Enacting entrepreneurial intent: The gaps between student needs and higher education capability. Education Training, 46(8/9), 454-463.

Elster, J. (1989). Social norms and economic theory. Journal of Economic Perspectives, 3(4), 99117.

Farah, S. A., \& Ali, H. A. (2018). A Study on perception of business students on the future job market: A case study of Umma University. International Journal of Scientific Research and Management, 6(04), 274-281. https://doi.org/10.18535/ijsrm/v6i4.emo6

Flora, Cornelia Butler. (2006). Are entrepreneurs born or made? Rural Development News, 4(28): 14-22.

Fritsch, M., \& Wyrwich, M. (2018). Regional knowledge, entrepreneurial culture, and innovative start-ups over time and space - an empirical investigation. Small Business and Economics, 2(51), 337-353. doi:10.1007/s11187-018-0016-6.

Fuller, J., Liu, Y., Bajaba, S., Marler, L., \& Pratt, J. (2018). Examining how the personality, selfefficacy, and anticipatory cognitions of potential entrepreneurs shape their entrepreneurial intentions. Personality and Individual Differences. 125, 120-125.

Gibson, D. (1991). Technology Companies and Global Markets: Programs, Policies and Strategies to Accelerate Innovation and Entrepreneurship. Rowman \& Littlefield Publisher, Inc., Maryland. p. 43-50.

Global Entrepreneurship Monitor. (2011). Report on Pakistan. International Council for Small Business. p. 23-33.

Hair, J. F., Hult, G. T., Ringle, C. M., \& Sarstedt, M. (2017). A primer on partial least squares structural equation modeling (PLS-SEM). California: Sage.

Hayes, T. and M. S. Malone. (2009). Entrepreneurs can lead us out of the crisis. Wall Street Journal, 8(2): A.15.

Lee, S. H., \& Wong. P. K. (2004). An Exploratory Study of technopreneurial intentions: a career anchor perspective. Journal of Business Venturing, 19(1), 7-28.

McGee, J. E., Peterson, M. S., Mueller, L., \& Sequeira, J. M. (2009). Entrepreneurial self-efficacy: Refining the measure. Entrepreneurship Theory and Practice, 33, 965-988.

Sarasvathy, S. D. (2002). Entrepreneurship as economics with imagination. Ruffin Series in Business Ethics, 26(3), 95-112.

Schumpeter, J. (1934). The Theory of Economic Development. Cambridge, MA: Harvard University Press.

Shane, S. (2003). A General Theory of Entrepreneurship. Cheltenham: Edward Elgar.

Stewart, W. H., \& Roth, P. L. (2004). Data quality affects meta-analytic conclusions: A response to entrepreneurial risk propensity. Journal of Applied Psychology, 89(2), 14-21. 
Townsend, D. M., Busenitz, L. W., \& Arthurs J. D. (2010). To start or not to start: outcome and ability expectations in the decision to start a new venture. Journal of Business Venturing, 25(2), 192-202.

Turker, D., \& Selcuk, S. S. (2009). Which factors affect entrepreneurial intention of university students? Journal of European Industrial Training, 33(2), 142-59. 